\title{
Mucoadhesive film containing a-mangostin shows potential role in oral cancer treatment
}

\author{
Piyawat Tangsuksan ${ }^{1}$, Jureeporn Chuerduangphui ${ }^{2}$, Chutha Takahashi Yupanqui ${ }^{3}$, Teerapol Srichana ${ }^{4,5}$,
}

Ekarat Hitakomate ${ }^{1}$, Chamsai Pientong ${ }^{6,7}$, Tipaya Ekalaksananan ${ }^{6,7}$ and Wipawee Nittayananta ${ }^{1 *}$ (D)

\begin{abstract}
Background: Oral cancer is often preceded by a mucosal lesion called an oral potentially malignant disorder (OPMD). Many plant-derived compounds are of value in medicine. The objectives of this study were to develop a soluble mucoadhesive film containing a-mangostin ( $(-M G)$, a compound extracted from the peel of mangosteen fruit, and determine its activities against oral cancer cells, against human papillomavirus type 16 (HPV-16) pseudovirus, and its anti-inflammatory properties.
\end{abstract}

Methods: A soluble mucoadhesive film containing a-MG was prepared. Oral squamous carcinoma cell line (SCC25), murine macrophage cells (RAW264.7), and human gingival fibroblast cell line were cultured. Anticancer activity and viability of SCC25 cells in response to a-MG film solution were determined by MTT assay. HPV-16 pseudovirus was constructed and effects of the film solution on attachment and post-attachment steps of the infection were investigated. Anti-inflammatory activity was assessed by nitric oxide (NO) inhibition. Fibroblast cell migration was determined by in vitro scratch assay.

Results: The soluble a-MG film showed cytotoxic effects on SCC25 cells in concentration $>125 \mu \mathrm{g} / \mathrm{ml}$ with $1 C_{50}$ of $152.5 \mu \mathrm{g} / \mathrm{ml}$. Antiviral activity against HPV-16 pseudovirus was observed at attachment step, but not at postattachment step. The film also possessed a strong anti-inflammatory effect and promoted wound healing without cytotoxicity.

Conclusions: Mucoadhesive film containing a-MG has a cytotoxic effect on oral squamous carcinoma cell line and an inhibitory effect on HPV-16 pseudovirus at attachment step. The a-MG film also shows a potent anti-inflammatory activity and enhances wound healing. Thus, the soluble a-MG film may have a potential role in treating oral cancer.

Keywords: Human papillomavirus, a-mangostin, Oral squamous cell carcinoma, Potentially malignant disorder, Wound healing

\section{Background}

Despite advances in diagnosis and treatment, oral squamous cell carcinoma (OSCC) is still a significant oral health problem $[1,2]$. It accounts for more than $90 \%$ of all oral cancers [3], with five-year survival rate of around $60 \%[4,5]$. OSCC is often preceded by a lesion called oral

\footnotetext{
*Correspondence: nwipawee@tu.ac.th

${ }^{1}$ Faculty of Dentistry, Thammasat University, Pathum Thani, Thailand

Full list of author information is available at the end of the article
}

potentially malignant disorder (OPMD), which includes a variety of conditions associated with chronic irritation and inflammation such as leukoplakia/erythroplakia, and oral lichen planus.

Plants are excellent sources of new bioactive compounds. Mangosteen pericarp contains various phytochemicals, which are used in traditional medicines [6]. Xanthones are the phytochemical groups in the mangosteen pericarp that are associated with different biological activities including cardioprotective, antioxidant, 
anti-inflammatory, antibacterial, anti-allergy, and anticancer activities [7]. Of all xanthones derived from the mangosteen pericarp, $\alpha-\mathrm{MG}$ is the most abundant and shows potent anticancer activities against many types of cancer cell lines including OSCC cell lines [8].

In addition to anticancer activity, other bioactivities of mangosteen peel extract have been reported. For instance, it has been demonstrated to reduce inflammation related to gingivitis in rats [9]. A study by Kresnoadi et al. [10] revealed that mangosteen pericarp extract could reduce the inflammation of post-tooth extraction in guinea pigs. Antimicrobial activity of $\alpha-M G$ against bacteria and fungi has been previously documented [11]. Moreover, antiviral activity of $\alpha$-MG has also been reported $[12,13]$.

Currently, there is no reliable molecular hallmark that can predict malignant transformation of OPMD. Thus, the preventive therapy of malignant transformation of the lesions is a reasonable approach. Because $\alpha-$ MG has been shown to possess various bioactivities, we hypothesized that mucoadhesive film containing $\alpha-M G$ would provide anticancer, anti-HPV16 and anti-inflammatory activities and promote wound healing.

\section{Methods}

\section{a-mangostin}

$\alpha$-MG used in this study was purchased from a local company in Thailand (Chemipan, Bangkok, Thailand). The compound was derived from pericarp of mangosteen extract (food grade).

\section{Preparation of mucoadhesive film containing a-mangostin} A soluble mucoadhesive film containing active ingredients $\alpha$-MG $(5 \mathrm{mg} / \mathrm{ml})$ was prepared by modifying the method previously described [14]. The film contained $\alpha$-MG 20\%, hydroxypropyl methylcellulose 1.2\% (HPMC E15, Methocel F4M, Dupont, Delaware, USA), polyethylene glycol 400 1.35\% (Chemipan, Bangkok, Thailand), glycerin $1.6 \%$, xylitol $1 \%$, citric acid $0.04 \%$ and deionized water $74.8 \%$. The HPMC was dissolved in water followed by polyethylene glycol, glycerin, xyletol and citric acid and $\alpha-M G$. The mixture was cast on a glass plate $75 \times 15 \mathrm{~mm}$ in size and dried in an oven at $70^{\circ} \mathrm{C}$ for $24 \mathrm{~h}$.

\section{Cell culture conditions Cell culture}

The murine macrophage cells (RAW264.7) were purchased from American Type Culture Collection (ATCC). RAW264.7 cell lines were grown in RPMI-1640 medium, supplemented with $10 \%$ fetal bovine serum (FBS), $0.1 \%$ sodium bicarbonate and $1 \%$ penicillin-streptomycin. A human embryonic kidney cell line, 293FT (Invitrogen, Carlsbad, CA, USA) was grown in Dulbecco's modified
Eagle's medium (DMEM; Gibco-Life Technologies, Grand Island, NY, USA) with 10\% FBS (Himedia, Mumbai, India), 0.1 mM MEM non-essential amino acids (Gibco), $6 \mathrm{mM} \mathrm{L-glutamine} \mathrm{(Gibco)} \mathrm{and} 500 \mu \mathrm{g} / \mathrm{mL} \mathrm{G418}$ sulfate (Calbiochem, Merck Biosciences Ltd., Nottingham, UK). The SCC25 cell line, Homo Sapiens tongue squamous cell carcinoma, purchased from ATCC, was maintained in culture system according to the previously described procedures [15], and cultured in DMEM (Gibco, NY, USA) with supplement of 15\% FBS (Gibco) and $100 \mathrm{U} / \mathrm{ml}$ antibiotic-antimycotic (Gibco). All cell lines were maintained at $37{ }^{\circ} \mathrm{C}$ in a humidified atmosphere of $5 \% \mathrm{CO}_{2}$.

\section{Cell viability assay}

Cytotoxicity was determined by the MTT assay as previously described [16]. In brief, the RAW264.7, 293FT, and SCC25 cell lines were cultured before being harvested with $0.25 \%$ trypsin-EDTA and then diluted in a fresh medium. The cells were seeded in 96-well plates with $2 \times 10^{4}$ (for 293FT cell line) and $1 \times 10^{4}$ cells/well (for RAW264.7 and SCC25 cell lines) and allowed to adhere at $37{ }^{\circ} \mathrm{C}$ for $24 \mathrm{~h}$. After that the medium was replenished with fresh medium (RPMI-1640 for RAW264.7, DMEM for 293FT and SCC25) along with the dissolved $\alpha$-MG mucoadhesive film solution $(6.25-50 \mu \mathrm{g} / \mathrm{ml}$ for RAW264.7 cells, $0.044-4400 \mu \mathrm{g} / \mathrm{ml}$ for $293 \mathrm{FT}$ cells and $1.95-259 \mu \mathrm{g} / \mathrm{ml}$ for SCC25 cells) and was then incubated for $24 \mathrm{~h}$. Ten microliters, of MTT solution $(5 \mathrm{mg} / \mathrm{ml}$ in PBS) was added to the 96-well plates. After $2 \mathrm{~h}$ of incubation, the medium was removed, and DMSO $(200 \mu \mathrm{l})$ was added to each well to dissolve the formazan solution. It was then measured with a microplate reader at 540-570 nm (Multiskan ${ }^{\mathrm{TM}}$ FC; Thermo Fisher Scientific, Waltham, MA, USA). The test samples were considered cytotoxic when the optical density (OD) of the sampletreated group was less than $80 \%$ of that in the control group. Cell viability was calculated using the following equation:

$$
\% \text { Cell viability }=\left[\mathrm{OD}_{\text {sample }} / \mathrm{OD}_{\text {control }}\right] \times 100
$$

\section{Antiviral activity against HPV-16 pseudovirus HPV-16 pseudovirus production}

The 293FT cells were seeded in $25 \mathrm{~cm}^{2}$ culture flask at $3 \times 10^{5}$ cells/flask and maintained for 4 days. The cells were co-transfected with p16SheLL $(6 \mu \mathrm{g})$ and pfwB $(6 \mu \mathrm{g})$ plasmids which were kindly provided by John $\mathrm{T}$. Schiller (Laboratory of Cellular Oncology, Bethesda, MD, USA) using Lipofectamine 20,000 (Invitrogen, Carlsbad, CA, USA) for $6 \mathrm{~h}$. After 4 days post-transfection, the transfected cells were harvested and lysed in a lysis buffer containing 0.5\% Brij 58 (Sigma-Aldrich, St. Louis, MO, 
USA), $0.2 \%$ RNase A (bovine pancreas, Sigma Chemical Company, St. Louis, MO, USA), $9.5 \mathrm{mM} \mathrm{MgCl}_{2}$ in PBS. The lysed cells were incubated at $37^{\circ} \mathrm{C}$ for $24 \mathrm{~h}$ and then chilled on ice for $5 \mathrm{~min}$ and kept at $-80^{\circ} \mathrm{C}$ for a long-term storage until use.

\section{Determination of HPV-16 pseudovirus titer}

The 293FT cells were seeded in a 96-well plate at $3 \times 10^{3}$ cells/well and incubated for $6 \mathrm{~h}$. HPV-16 pseudovirus stock was diluted to 1:5000, 1:10,000, 1:20,000 and 1:40,000. Each diluted viral stock was added into the cells and incubated at $37{ }^{\circ} \mathrm{C}, 5 \% \mathrm{CO}_{2}$ for 4 days. The 293FT cells which were infected by HPV-16 pseudovirus, displayed green fluorescence under a fluorescent microscope (Olympus BX51, Olympus Co., Ltd., Tokyo, Japan). The cells were harvested and then counted by a hemocytometer (Marienfeld GmbH, Marienfeld, Germany) under light and fluorescent microscope (Olympus). The infectious titer is interpreted as transducing units (TU)/ $\mathrm{ml}$ and was calculated by the formula:

$$
\begin{aligned}
\text { Viral titer }(\mathrm{TU} / \mathrm{ml})= & \% \text { infection } \times(\text { cell density seeded }) \\
& \times \text { dilution factor/volume of viral stock }
\end{aligned}
$$

\section{Cytotoxicity}

The 293FT cells were seeded into a 96-well plate at $2 \times 10^{4}$ cells/well and then incubated for $24 \mathrm{~h}$. Prior to cell viability test, the $\alpha-M G$ mucoadhesive film was dissolved in the culture medium resulting as a solution sample. The cells were then treated with various concentrations of the film solution sample $(0,0.4,0.6,0.8,1.0,2.0$ and $4.0 \mu \mathrm{g} /$ $\mathrm{ml}$ ) for $48 \mathrm{~h}$.Ten microliters of $5 \mathrm{mg} / \mathrm{ml}$ MTT (Sigma, St. Louis, MO, USA) was added to each well. After $4 \mathrm{~h}$, the medium was removed and the water-insoluble purple formazan particles were dissolved in $100 \mu \mathrm{l}$ DMSO solution. The absorbance was read at $540 \mathrm{~nm}$ with a microplate reader (Multiskan GO, ThermoScientific, USA).

\section{Determination of anti-HPV-16 pseudovirus infection at attachment step}

The 293FT cells were seeded in a 96-well plate at $3 \times 10^{3}$ cells/well and cultured for 4 days. HPV-16 pseudoviruses (MOI 0.05 and 0.5 ) were treated with or without the $\alpha$-MG mucoadhesive film solution $(0,0.2,0.4$, $0.8,2.0,4.0$ and $8.0 \mu \mathrm{g} / \mathrm{ml}$ ) at $37^{\circ} \mathrm{C}$ for $1 \mathrm{~h}$. The treated pseudoviruses were adsorbed on the cells and incubated at $37^{\circ} \mathrm{C}$ for $4 \mathrm{~h}$. Unattached pseudoviruses were removed and then incubated in complete medium at $37^{\circ} \mathrm{C}$ for $72 \mathrm{~h}$.

\section{Determination of anti-HPV-16 pseudovirus infection at post-attachment step}

The 293FT cells were seeded in a 96-well plate at $3 \times 10^{3}$ cells/well and cultured for 4 days. HPV-16 pseudoviruses (MOI 0.05 and 0.5 ) were adsorbed on the cells and incubated at $25{ }^{\circ} \mathrm{C}$ for $2 \mathrm{~h}$ to allow HPV-16 pseudovirus to bind to their receptors but not enter into the cells. After removing unattached pseudoviruses, the cells were maintained in complete media with or without the $\alpha$-MG mucoadhesive film solution $(0,0.2,0.4,0.8,2.0$, 4.0 and $8.0 \mu \mathrm{g} / \mathrm{ml}$ ) at $37^{\circ} \mathrm{C}$ for $72 \mathrm{~h}$.

To determine anti-HPV-16 pseudovirus infection both at attachment step and at post-attachment step, heparin $(400 \mu \mathrm{M})$ was used as a positive control. HPV-16 pseudovirus-infected cells were detected by observing green fluorescence under a fluorescent microscope. The cells were harvested and then counted by a hemocytometer under light and a fluorescent microscope to analyze the percentage of inhibition.

\section{In vitro anti-inflammatory study Nitric oxide (NO) inhibition}

Anti-inflammatory activity of the $\alpha$-MG mucoadhesive film solution was measured by a method modified from Sae-Wong et al. [16]. In brief, the RAW264.7 macrophage cell lines were seeded in 96-well plates $\left(1 \times 10^{4}\right.$ cells/ well) and allowed to adhere for $2 \mathrm{~h}$ at $37{ }^{\circ} \mathrm{C}$ in a humidified atmosphere containing $5 \% \mathrm{CO}_{2}$. Two hours later, the non-adherent cells and medium were removed and the adherent cells were cultured in a fresh medium containing $1 \mu \mathrm{g} / \mathrm{ml}$ LPS (lipopolysaccharides L4005, SigmaAldrich, Missouri, USA) and various concentrations of the $\alpha$-MG mucoadhesive film solution for $24 \mathrm{~h}$. NO production in each well was assessed by measuring the accumulation of nitrite $\left(\mathrm{NO}_{2}\right)$ in the culture medium using Griess reagent. One hundred $\mu \mathrm{l}$ of supernatant was mixed with $100 \mu \mathrm{l}$ of Griess reagent and the optical density (OD) was detected at $570 \mathrm{~nm}$. L-nitro-arginine (L-NA), which is NO synthase inhibitor, was used as a positive control $(6.25-50 \mu \mathrm{g} / \mathrm{ml})$. The percentage of inhibition of NO production was calculated using the following equation.

$$
\begin{aligned}
& \text { NO Inhibition }(\%) \\
& =\frac{[(\text { control }- \text { blank of control })-(\text { sample }- \text { blank of sample })]}{(\text { control }- \text { blank of control })}
\end{aligned}
$$

\section{In vitro scratch assay}

Human gingival fibroblast cell line was seeded into 6-well plates at a density of $1 \times 10^{6}$ cells/well. A linear scratch was generated with a sterile pipette tip in the monolayer when it was confluently formed. Cellular debris was removed by washing three times with $3 \mathrm{ml}$ PBS and replaced with $2 \mathrm{ml}$ of complete medium containing the $\alpha$-MG mucoadhesive film solution $(29.20 \mathrm{mg} / \mathrm{ml})$, while complete medium without the 

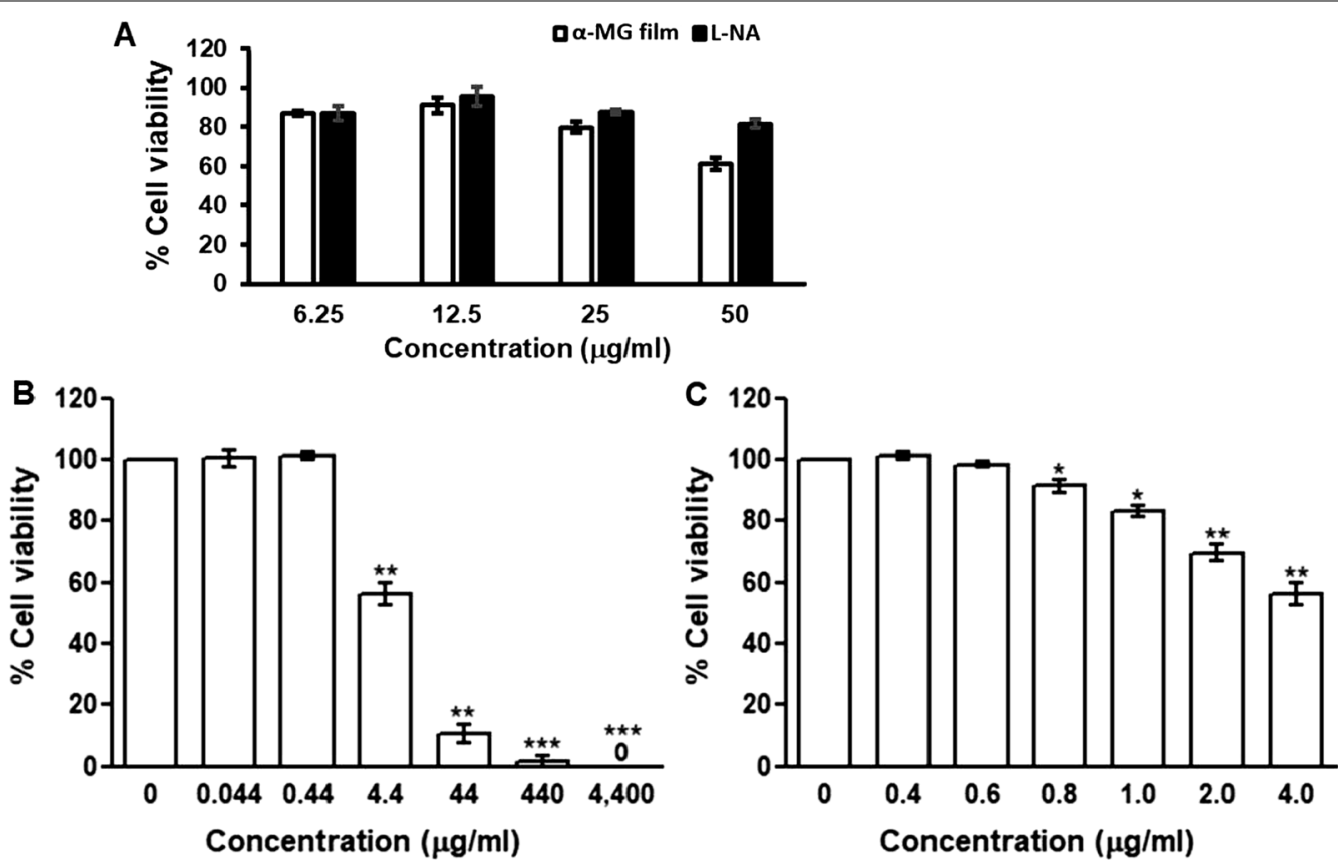

Fig. 1 Cytotoxicity of mucoadhesive film solution $(6.25-50 \mathrm{\mu g} / \mathrm{ml}$ ) containing a-mangostin (a-MG, $5 \mathrm{mg} / \mathrm{ml}$ ) by MTT assay on RAW264.7 macrophage cell line (A), on 293FT cells at ten-fold dilution 0 to $4400 \mu \mathrm{g} / \mathrm{ml}(\mathbf{B})$ and at $0-4.0 \mu \mathrm{g} / \mathrm{ml}$ (C). Data presented as mean \pm SEM $(n=4)$. Differences in percentage of cell viability were statistically analyzed using One-way ANOVA. ${ }^{*},{ }^{* *}$ and ${ }^{* * *}$ denote statistically significant differences as $P<0.05,0.01$ and 0.001 , respectively

film solution served as a negative control. Photographs were taken at a $10 \times$ magnification using a microphotograph on day 0 , then plates were incubated at $37^{\circ} \mathrm{C}$ with $5 \% \mathrm{CO}_{2}$ and photographs were taken at days 1 and 2 . The images acquired for each sample were further analyzed quantitatively by using computing software ImageJ [17]. The distance of each scratch closure was determined by comparing the images from day $0-2$, and the percentage migration rate was calculated. Two scratches were made in each well (left and right) and six random microscopic fields were considered per scratch. The average of the left scratch and the right scratch were taken separately. The percentage of migration was calculated for the left scratch and then the right scratch using the following equation:

\%Migration rate $=\frac{\text { average distance between scratch day } 0-\text { average distance between scratch day } 1}{\text { average distance between scratch day } 0}$

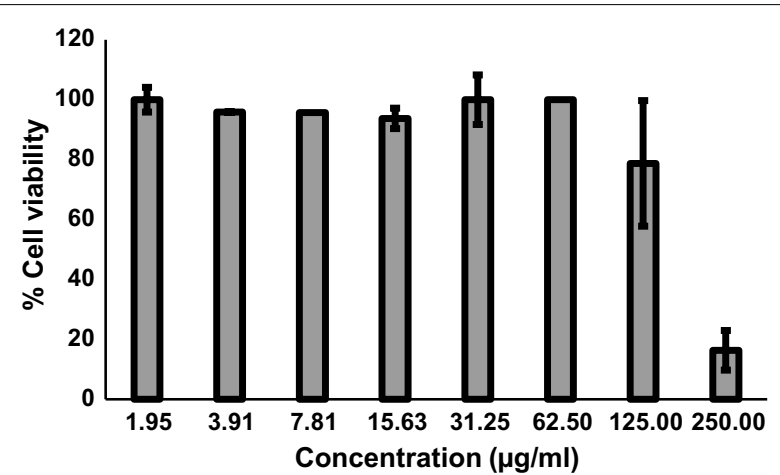

Fig. 2 Effects of mucoadhesive film containing a-MG on viability of SCC25 cell line. Viability of SCC25 cell line in response to the a-MG film solution was determined by MTT assay. Cytotoxic effects was observed when the concentration of the film was $>125 \mu \mathrm{g} / \mathrm{ml}$ with the $\mid C_{50}$ of $152.5 \mu \mathrm{g} / \mathrm{ml}$

\section{Statistical analysis}

Statistical analysis was performed using Prism5 software (GraphPad, San Diego, CA, USA). Comparisons between untreated and treated groups were investigated by Student's t-tests. The data are expressed as mean \pm SEM (standard error of the mean). The symbols $*$, *** and ${ }^{* * * *}$ are denoted as statistically significant differences $(P<0.05$, 0.01 and 0.001 , respectively).

\section{Results}

Cytotoxicity of mucoadhesive film containing a-mangostin The cytotoxicity of the $\alpha-M G$ mucoadhesive film was determined by MTT assay using murine macrophage cell line (RAW264.7 cells). The $\mathrm{IC}_{50}$ of the $\alpha$-MG film and L-NA was $64.51 \mu \mathrm{g} / \mathrm{ml}$ and $125.80 \mu \mathrm{g} / \mathrm{ml}$, respectively. 


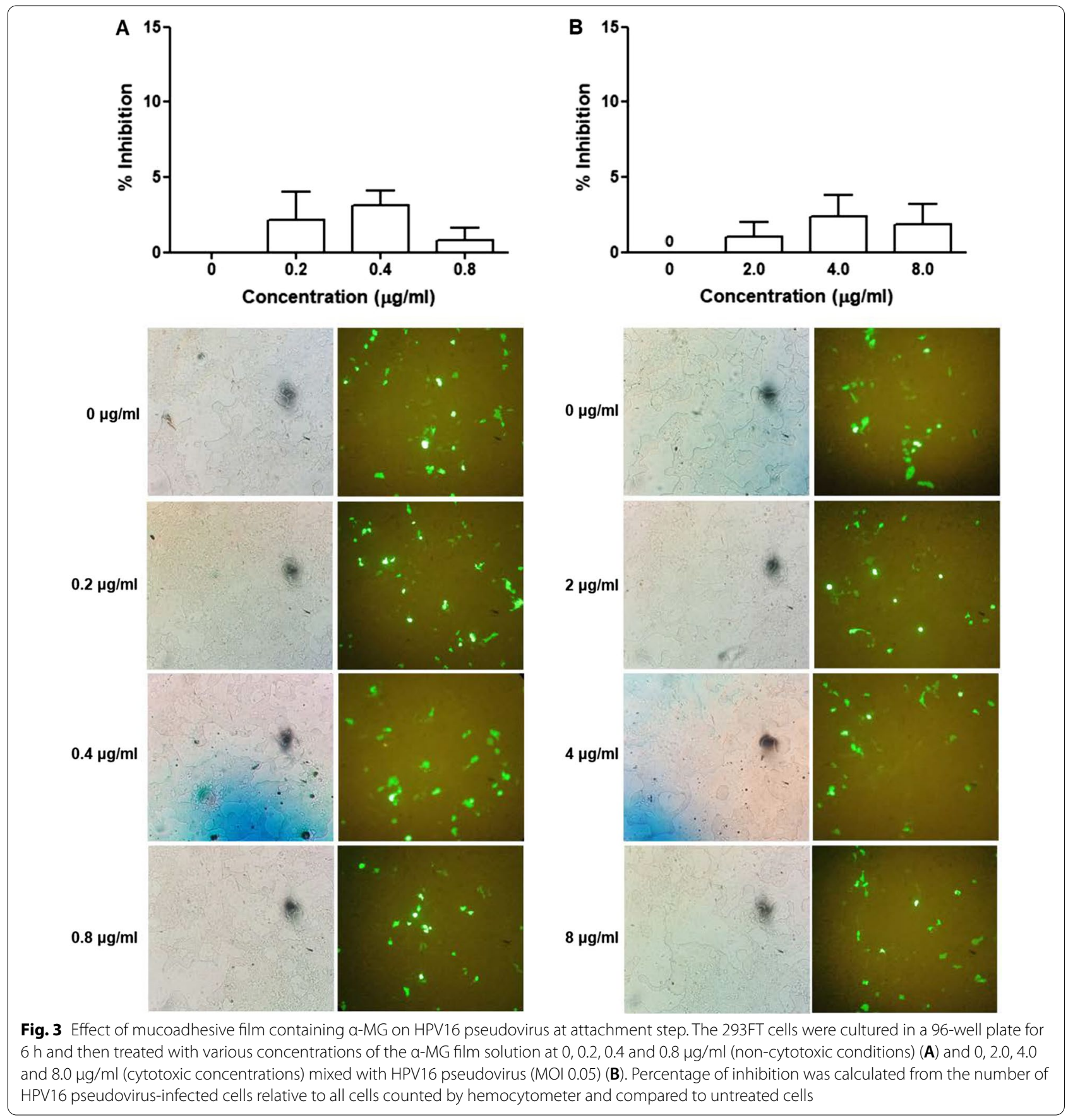

The film solution was not toxic to the cells, with $80 \%$ survival at the maximum concentration of $25 \mu \mathrm{g} / \mathrm{ml}$ concentrations (Fig. 1A). An increase in concentration of the film solution led to a decrease in cell viability, and the toxicity was observed at the concentration of $\geq 50 \mu \mathrm{g} / \mathrm{ml}$. In contrast, L-NA standard was applied to the cells at a concentration of $50 \mu \mathrm{g} / \mathrm{ml}$ and the cell viability remained more than $80 \%$.
The cytotoxic effect of the $\alpha$-MG mucoadhesive film was also determined in 293FT cells. Various concentrations of the film solution $(0-4400 \mu \mathrm{g} / \mathrm{ml})$ were screened and analyzed for $48 \mathrm{~h}$ after treatment. The concentration of the film at $\leq 4.4 \mu \mathrm{g} / \mathrm{ml}$ had $\geq 50 \%$ of cell viability (Fig. 1B). Subsequently, the treatment with the concentration of the film at $0,0.4,0.6,0.8,1.0,2.0$ and $4.0 \mu \mathrm{g} /$ $\mathrm{ml}$ was performed. The cell viability was not decreased 



Fig. 4 Effect of mucoadhesive film containing a-MG on HPV16 pseudovirus at post-attachment step. The 293FT cells were cultured in 96-well plate for $6 \mathrm{~h}$ and then were added with HPV16 pseudovirus (MOI 0.05) for $4 \mathrm{~h}$ before treated with various concentrations of the a-MG film solution at $0,0.2,0.4$ and $0.8 \mathrm{\mu g} / \mathrm{ml}$ (non-cytotoxic condition) (A) and 0, 2.0, 4.0 and $8.0 \mu \mathrm{g} / \mathrm{ml}$ (cytotoxic concentration) (B). Percentage of inhibition was calculated from the number of HPV16 pseudovirus-infected cells relative to all cells counted by hemocytometer and compared to untreated cells

with the concentration of the film solution at $\leq 0.8 \mu \mathrm{g} / \mathrm{ml}$ (Fig. 1C).

\section{Anticancer activity of mucoadhesive film containing a-mangostin}

Viability of SCC25 cell line in response to the mucoadhesive film containing $\alpha$-MG was determined by MTT assay. The results showed cytotoxic effects on the cell viability when the concentration of the film solution was $>125 \mu \mathrm{g} / \mathrm{ml}$ with the $\mathrm{IC}_{50}$ of $152.5 \mu \mathrm{g} / \mathrm{ml}$ (Fig. 2).

\section{Antiviral activity of mucoadhesive film containing a-mangostin}

Effect on HPV-16 pseudovirus infection at attachment step

To study the effects of the mucoadhesive film containing $\alpha-\mathrm{MG}$ on HPV-16 pseudovirus at attachment step, HPV16 pseudovirus at MOI 0.05 and 0.5 was treated with or 


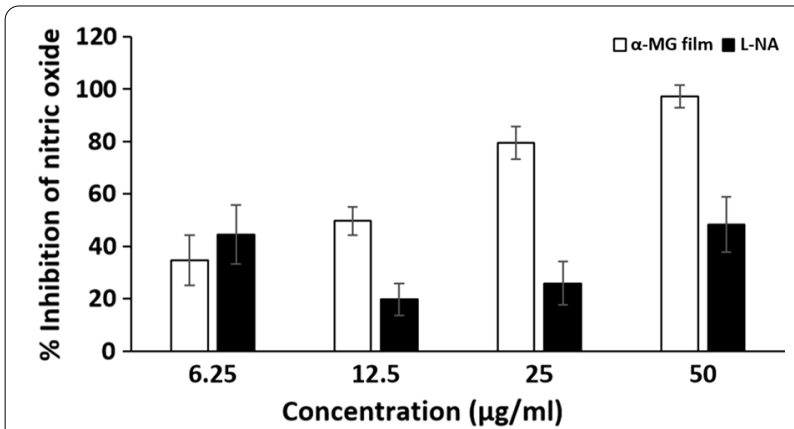

Fig. 5 Anti-inflammatory activity of mucoadhesive film containing a-MG. Anti-inflammatory activity of mucoadhesive film containing a-MG $(5 \mathrm{mg} / \mathrm{ml})$ was determined by percent inhibition of $\mathrm{NO}$ in RAW264.7 macrophage cell lines. The percentage of inhibition of NO production in the cells after treated with the a-MG film solution $(6.25-50 \mu \mathrm{g} / \mathrm{ml})$ was dose-dependent. L-NA served as positive control. Data presented as mean $\pm \operatorname{SEM}(n=4)$

without the film at concentrations of $0,0.2,0.4,0.8 \mu \mathrm{g} /$ $\mathrm{ml}$ (non-cytotoxic concentrations), and 0, 2.0, 4.0 and $8.0 \mu \mathrm{g} / \mathrm{ml}$ (cytotoxic concentrations), incubated for $1 \mathrm{~h}$ and added to the cells. After $72 \mathrm{~h}$ treatment, the result showed that the $\alpha$-MG film reduced the percentage of HPV-16 pseudovirus-infected cells in the attachment step only in MOI 0.05 (Fig. 3) but not in MOI 0.5 (data not shown). However, no significant difference was found in contrast to untreated cells.

\section{Effect on HPV-16 pseudovirus infection at post-attachment step}

To study the effects of the mucoadhesive film containing $\alpha$-MG on HPV-16 pseudovirus at post-attachment step, HPV-16 pseudoviruses at MOI 0.05 and 0.5 were adsorbed on 293FT cells and incubated for $4 \mathrm{~h}$ to allow pseudoviruses to bind to their receptors on the cell surface. The $\alpha-M G$ films solution at concentrations of $0,0.2$, $0.4,0.8 \mu \mathrm{g} / \mathrm{ml}$ (non-cytotoxic concentrations), and 0, 2.0, 4.0 and $8.0 \mu \mathrm{g} / \mathrm{ml}$ (cytotoxic concentrations) were added to pseudovirus-attached cells and incubated for $72 \mathrm{~h}$. The result showed that the percentage of HPV-16 pseudovirus-infected cells in the post-attachment step was not decreased in either MOI 0.05 (Fig. 4) or 0.5 infection (data not shown).

\section{Anti-inflammatory activity of mucoadhesive film containing a-mangostin}

In order to determine anti-inflammatory activity, percent inhibition of NO was assessed. The anti-inflammatory activity of the mucoadhesive film containing $\alpha-M G$ was evaluated in RAW 264.7 cells. The film demonstrated the inhibition of NO in a dose-dependent manner (Fig. 5). Of interest, NO inhibition activity of the $\alpha-M G$ film was found to be better than L-NA standard. The $\mathrm{IC}_{50}$ of the $\alpha$-MG film was about four times less concentrated than that of L-NA standard.

\section{Effects of mucoadhesive film containing a-mangostin on cell migration}

Measurement of cell migration was determined in vitro by scratch assay. A human gingival fibroblast layer was scratched and treated with the $\alpha$-MG mucoadhesive film solution $(29.20 \mu \mathrm{g} / \mathrm{ml})$ at 0,24 and $48 \mathrm{~h}$ after incubation. It was noted that cell migration was more efficient in the presence of the film than the control both at $24 \mathrm{~h}$ and $48 \mathrm{~h}$ (Fig. 6).

\section{Discussion}

This study demonstrated that mucoadhesive film containing $\alpha-M G$ affects viability of oral cancer cell line and seems to inhibit HPV-16 pseudovirus at the attachment step of the infection, but not at the post-attachment step. The $\alpha-M G$ film also shows strong anti-inflammatory activity and may promote wound healing without cytotoxic effects at a therapeutic dose.

A previous study by Kwak et al. [8] reported that $\alpha$-MG inhibits cell proliferation and induces cell death in OSCC cells in a dose- and time-dependent manner with little to no effect on normal human periodontal ligament cells. Moreover, $\alpha$-MG was shown to decrease cell viability by inducing apoptosis and cell cycle arrest in YD-15 tongue mucoepidermoid carcinoma cells [18]. Cytotoxic effect of $\alpha$-MG was also reported in other types of cancer cells, including colon and prostate cancers $[19,20]$. In our study, the mucoadhesive film containing $\alpha$-MG shows anticancer activity at a relative high dose when compared to that tested with the compound alone reported in the literature [8]. This may be due to the fact that some of the $\alpha-M G$ may be entrapped by other ingredients when the film is formulated, and thus its anticancer activity might be reduced. Optimization of the mucoadhesive film will be needed for enhancing the cytotoxic effect observed in this study [21]. The difference may also result from the difference in cell lines used in the study.

In the present study, the mucoadhesive film containing $\alpha$-MG seems to inhibit HPV-16 pseudovirus at the attachment step of infection. Previous studies reported that the frequency of HPV virus in carcinoma and potentially malignant cases ranges from 0 to $100 \%$ [22]. HPV has been associated with head and neck squamous cell carcinoma. However, some studies revealed that only a small proportion of OSCC appears to be caused by HPV $[23,24]$. The prevalence of high risk HPV in OSCC cases from various countries has been reported, with Asian countries tending to have a lower prevalence of high risk HPV compared to those reported from western regions 


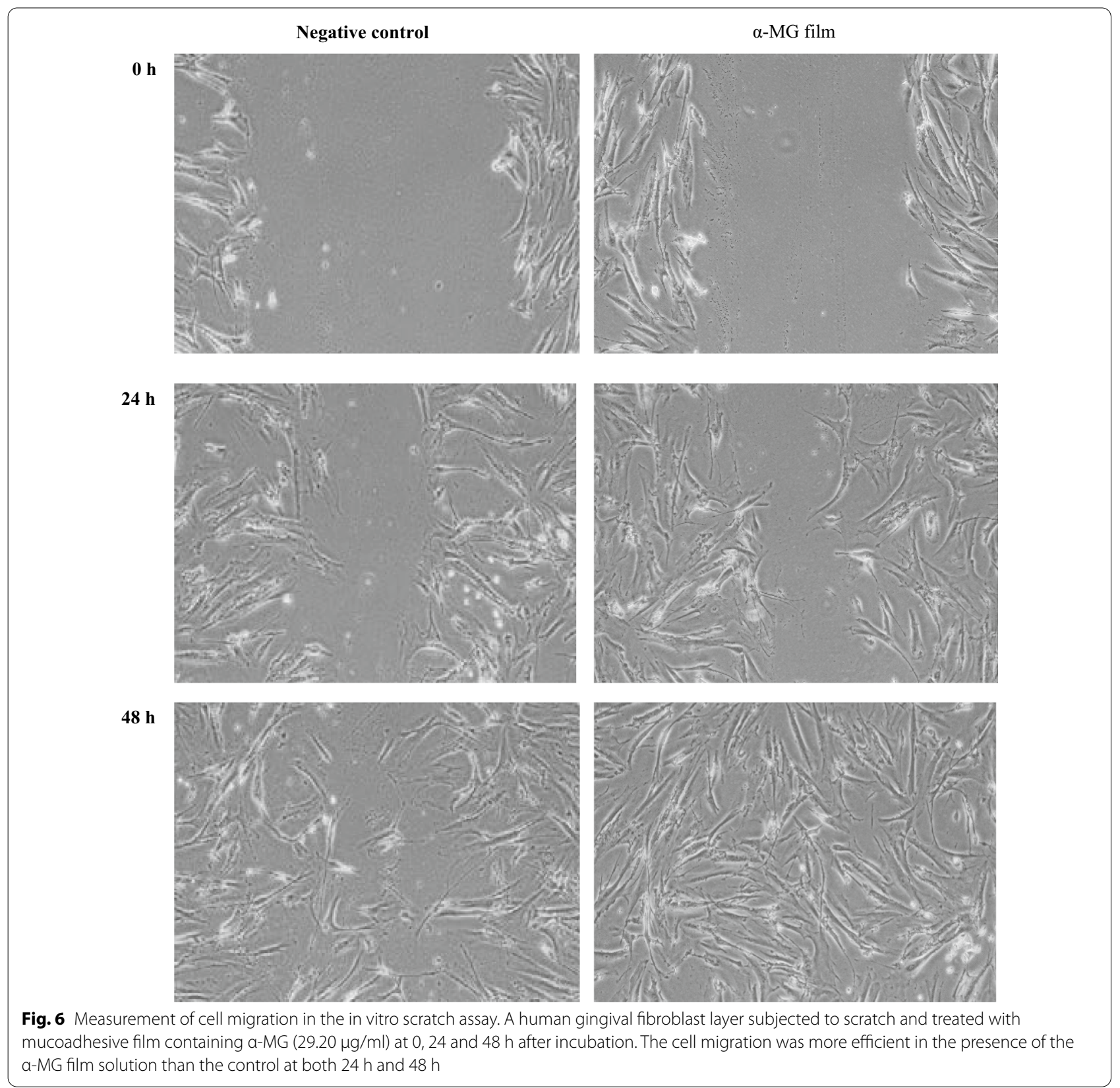

$[25,26]$. The difference in frequencies in the studies has been attributed to the type of samples collected, methodology used to study the samples, and the selected patient group $[27,28]$. Thus, the role of HPV infection on promoting malignant transformation of some OPMD lesions into OSCC remains unclear and should be further investigated [27].

In the present study, the mucoadhesive film containing $\alpha$-MG shows more potent anti-inflammatory activity than that of L-NA standard, and seems to promote wound healing. These effects may help to control malignant transformation as OPMD include a variety of lesions that are commonly associated with chronic irritation and inflammation such as leukoplakia/ erythroplakia, or ulcerative lesions in some cases of oral lichen planus and discoid lupus erythematosus. As chronic inflammation is a well-known risk factor for malignant changes [29], transformation of lesions related to inflammatory disorders such as oral lichen planus and discoid lupus erythematosus into OSCC may be preventable to some extent by reducing inflammation. In particular, in those with risk factors, which may synergistically 
contribute to OSCC, such as smoking, alcohol consumption, use of smokeless tobacco and betel quid chewing [30], the $\alpha$-MG film may be applied to control inflammation and promote healing of those OPMD lesions and thus may help to prevent progression of the lesions into OSCC.

\section{Conclusions}

This study demonstrated that the mucoadhesive film containing $\alpha-M G$ has a strong anti-inflammatory effect and promotes wound healing without cytotoxicity at a therapeutic dose. The film also shows a cytotoxic effect on the viability of SCC25 cell lines and inhibits HPV-16 pseudovirus infection at the attachment step. Thus, the mucoadhesive film containing a-MG may have a potential role in oral cancer treatment. Further studies should be performed in other SCC cell lines and other HPV genotypes associated with OSCC.

\begin{abstract}
Abbreviations
a-MG: a-Mangostin; ATCC: American type culture collection; DMEM: Dulbecco's modified Eagle's medium; DMSO: Dimethyl sulfoxide; EDTA: Ethylenediaminetetraacetic acid; FBS: Fetal bovine serum; HPMC: Hydroxypropyl methylcellulose; HPV-16: Human papilloma virus type 16; MTT: (3-(4,5-Dimethylthiazol-2-yl)-2,5-Diphenyltetrazolium Bromide); NO: Nitric oxide; OD: Optical density; OSCC: Oral squamous cell carcinoma; PBS: Phosphate buffer saline; OPMD: Oral potentially malignant disorder; TU: Transducing units.
\end{abstract}

\section{Acknowledgements}

The authors wish to thank Dr. Phunuch Muhamad, Ms. Luxsana Panrit, and Ms. Titpawan Nakpeng for technical support, and Ms. Rachel Djamaludin for her kind help on editing the manuscript.

\section{Authors' contributions}

WN designed the study. PT, JC, CTU, TS, EH performed the study and collected data. JC, CTU, TS, CP, TE and WN analyzed and interpreted the data. JC, CTU, TS, and WN drafted the manuscript. JC, CTU, TS, EH, CP, TE and WN revised the manuscript. All authors approved the final version of the manuscript and agree to be accountable for all aspects of the work. All authors read and approved the final manuscript.

\section{Funding}

This study was supported by Thammasat University Research Fund, Contract No. TUFT 20/2562.

\section{Availability of data and materials}

The datasets generated and/or analyzed during the current study are not publicly available, but are available from the corresponding author on reasonable request.

\section{Declarations}

Ethics approval and consent to participate

Not applicable.

\section{Consent to publish}

Not applicable.

\section{Competing interests}

The authors declare that they have no competing interests.

\section{Author details}

${ }^{1}$ Faculty of Dentistry, Thammasat University, Pathum Thani, Thailand. ${ }^{2}$ Department of Microbiology, Faculty of Science, Kasetsart University, Bangkok, Thailand. ${ }^{3}$ Center of Excellence in Functional Foods and Gastronomy, Faculty of Agro-Industry, Prince of Songkla University, Hat Yai, Songkhla, Thailand. ${ }^{4}$ Drug Delivery System Excellence Center, Faculty of Pharmaceutical Sciences, Prince of Songkla University, Hat Yai, Songkhla, Thailand. ${ }^{5}$ Department of Pharmaceutical Technology, Faculty of Pharmaceutical Sciences, Prince of Songkla University, Hat Yai, Songkhla, Thailand. ${ }^{6}$ Department of Microbiology, Faculty of Medicine, Khon Kaen University, Khon Kaen, Thailand. ${ }^{7} \mathrm{HPV}$ and EBV and Carcinogenesis Research Group, Khon Kaen University, Khon Kaen, Thailand.

Received: 20 January 2021 Accepted: 22 September 2021

Published online: 10 October 2021

\section{References}

1. Chen SF, Nien S, Wu CH, et al. Reappraisal of the anticancer efficacy of quercetin in oral cancer cells. J Chin Med Assoc. 2013;76:146-52.

2. Warnakulasuriya S. Prognostic and predictive markers for oral squamous cell carcinoma: the importance of clinical, pathological and molecular markers. Saudi J Med Med Sci. 2014;2:12-6.

3. Feller $L$, Lemmer J. Oral squamous cell carcinoma: epidemiology, clinical presentation and treatment. J Cancer Ther. 2012;3:263-8.

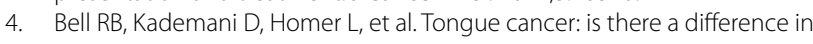
survival compared with other subsites in the oral cavity? J Oral Max Surg. 2007:65:229-36.

5. Jemal A, Siegel R, Ward E. Cancer statistics, 2006. CA Cancer J Clin. 2006;56:106-30.

6. Xu Q, Ma J, Lei J, et al. a-Mangostin suppresses the viability and epithelialmesenchymal transition of pancreatic cancer cells by downregulating the PI3K Akt pathway. Biomed Res Int. 2014;2014:1-2. https://doi.org/10. $1155 / 2014 / 546353$

7. Pedraza-Chaverri J, Cárdenas-Rodríguez N, Orozco-lbarra M, et al. Medicinal properties of mangosteen (Garcinia mangostana). Food Chem Toxicol. 2008;46:3227-39.

8. Kwak HH, Kim IR, Kim HJ, et al. a-Mangostin induces apoptosis and cell cycle arrest in oral squamous cell carcinoma cell. Evid Based Complement Alternat Med. 2016;2016:1-10. https://doi.org/10.1155/2016/53524 12.

9. Putri K, Darsono L, Mandalas H. Anti-inflammatory properties of mangosteen peel extract onthe mice gingival inflammation healing process. Padjadjaran J Dent. 2017;29:190-5.

10. Kresnoadi U, Ariani MD, Djulaeha E, et al. The potential of mangosteen (Garcinia mangostana) peel extract, combined with demineralized freeze-dried bovine bone xenograft, to reduce ridge resorption and alveolar bone regeneration in preserving the tooth extraction socket. J Indian Prosth Soc. 2017;17:282-8.

11. Nittayananta W, Limsuwan S, Srichana T, et al. Oral spray containing plant-derived compounds is effective against common oral pathogens. Arch Oral Biol. 2018;90:80-5.

12. Sugiyanto Z, Yohan B, Hadisaputro S, et al. Inhibitory effect of alphamangostin to dengue virus replication and cytokines expression in human peripheral blood mononuclear cells. Nat Prod Bioprospect. 2019:9:345-9.

13. Tarasuk M, Songprakhon P, Chimma P, et al. Alpha-mangostin inhibits both dengue virus production and cytokine/chemokine expression. Virus Res. 2017;240:180-9.

14. Ahn JS, Choi HK, Chun MK, et al. Release of triamcinolone acetonide from mucoadhesive polymer composed of chitosan and poly (acrylicacid) in vitro. Biomaterials. 2002;23:1411-6.

15. Prgomet Z, Axelsson L, Lindberg P, et al. Migration and invasion of oral squamous carcinoma cells is promoted by WNT5A, a regulator of cancer progression. J Oral Pathol Med. 2015;44:776-84.

16. Sae-Wong C, Matsuda H, Tewtrakul S, et al. Suppressive effect of methoxyflavonoids isolated from Kaempferiaparviflora on inducible nitric oxide synthase (iNOS) expression in RAW 264.7 cells. J Ethnopharmacol. 2011;136:488-95 
17. Schneider CA, Rasband WS, Eliceiri KW. NIH image to Image J: 25 years of image analysis. Nat Methods. 2012;9:671-5.

18. Lee $H N$, Jang HY, Kim HJ, et al. Antitumor and apoptosis-inducing effects of a-mangostin extracted from the pericarp of the mangosteen fruit (Garcinia mangostana L.) in YD-15 tongue mucoepidermoid carcinoma cells. Int J Mol Med. 2016;37:939-48.

19. Chitchumroonchokchai C, Thomas-Ahner JM, Li J, et al. Anti-tumorigenicity of dietary a-mangostin in an HT-29 colon cell xenograft model and the tissue distribution of xanthones and their phase II metabolites. Mol Nutr Food Res. 2012;57:203-11.

20. Johnson JJ, Petiwala SM, Syed DN, et al. a-Mangostin, a xanthone from magosteen fruit, promotes cell cycle arrest in prostate cancer and decreases xenograft tumor growth. Carcinogenesis. 2012;33:413-9.

21. Karki S, Kim H, Na S, et al. Thin film as an emerging platform for drug delivery. Asian J Pharm Sci. 2016;11:559-74.

22. Panneerselvam K, Rameshkumar A, Rajkumar K, et al. Detection of human papillomavirus 16 and 18 in patients with oral squamous cell carcinoma and potentially malignant oral disorders in South Indian population: a pilot study. J Cancer Res Ther. 2019;15:571-5.

23. Chi AC, Day TA, Neville BW. Oral cavity and oropharyngeal squamous cell carcinoma-an update. CA Cancer J Clin. 2015;65:401-21.

24. Siegel R, Miller K, Jemal A. Cancer statistics, 2015. CA Cancer J Clin. 2015;65:5-29.
25. Paz IB, Cook N, Odom-Maryon T, et al. Human papillomavirus (HPV) in head and neck cancer: an association of HPV 16 with squamous cell carcinoma of Waldeyer's tonsillar ring. Cancer. 1997;79:595-604.

26. Lee SY, Cho NH, Choi EC, et al. Relevance of human papilloma virus (HPV) infection to carcinogenesis of oral tongue cancer. Int J Oral Max Surg. 2010;39:678-83.

27. Giovannelli L, Campisi G, Lama A, et al. Human papillomavirus DNA in oral mucosal lesions. J Infect Dis. 2002;185:833-6.

28. Campisi G, Panzarella V, Giuliani M, et al. Human papillomavirus: Its identity and controversial role in oral oncogenesis, premalignant and malignant lesions (review). Int J Oncol. 2007;30:813-23.

29. Fridman WH, Pagès F, Sautès-Fridman C, et al. The immune contexture in human tumours: impact on clinical outcome. Nat Rev Cancer. 2012;12:298-306.

30. Dionne KR, Warnakulasuriya S, Zain RB, et al. Potentially malignant disorders of the oral cavity: current practice and future directions in the clinic and laboratory. Int J Cancer. 2015;136:503-15.

\section{Publisher's Note}

Springer Nature remains neutral with regard to jurisdictional claims in published maps and institutional affiliations.
Ready to submit your research? Choose BMC and benefit from:

- fast, convenient online submission

- thorough peer review by experienced researchers in your field

- rapid publication on acceptance

- support for research data, including large and complex data types

- gold Open Access which fosters wider collaboration and increased citations

- maximum visibility for your research: over $100 \mathrm{M}$ website views per year

At BMC, research is always in progress.

Learn more biomedcentral.com/submissions 